\title{
PERANCANGAN APLIKASI PERSEDIAAN OBAT PADA TOKO SEHAT MAKMUR DI JAKARTA TIMUR BERBASIS JAVA NETBEANS
}

\author{
Pricilla Marina \\ Program Studi Informatika, Fakultas Teknik dan Ilmu Komputer, Universitas Indraprasta PGRI \\ Jalan Raya Tengah No 80, Kelurahan Gedong, Pasar Rebo, Jakarta Timur \\ Pricillamarina88@gmail.com
}

\begin{abstract}
Abstrak
Tujuan penelitian ini adalah menghasilkan rancangan aplikasi persediaan obat di Toko Sehat Makmur dan untuk memberikan manfaat melalui aplikasi sistem persediaan serta menghasilkan aplikasi yang informatif dan interaktif. Metode penelitian yang digunakan oleh peneliti dalam penelitian ini adalah Metode Research and Development adalah suatu proses penelitian pengembangan atas dua jenis, yakni pertama penelitian yang difokuskan pada evaluasi atas produk atau program tertentu dengan tujuan untuk mendapatkan gambaran tentang proses pengembangan serta mempelajari kondisi yang mendukung bagi implementasi program tersebut. Peneliti menarik kesimpulan bahwa aplikasi yang telah dibangun dapat mempermudah pegawai dalam melakukan proses persedian obat. Dengan Aplikasi ini, pengguna menjadi lebih efektif dan efisien serta data obat dan data penjualan tersusun rapih dalam basis data.
\end{abstract}

Kata Kunci: Persediaan Obat, Penjualan, Sistem Informasi.

\begin{abstract}
The purpose of this research is to produce a design application of drug supplies at Toko Sehat Makmur and to provide benefits through the application of inventory system as well as produce informative and interactive applications. The research method used by researchers in this research is the Research and Development Method is a development research process of two types, namely the first research focused on evaluating a particular product or program with the aim of getting an idea of the development process and studying the conditions that support the implementation of the program. The researchers concluded that the applications that have been built can make it easier for employees to carry out the process of drug distribution. With this App, users become more effective and efficient and drug data and sales data are organized neatly in the database.
\end{abstract}

Keywords: Drug Inventory, Sales, Information Systems.

\section{PENDAHULUAN}

Informasi dalam aplikasi ini khususnya yang dibuat berbasis java netbeans dapat berupa pengetahuan, ataupun perhitungan-perhitungan untuk mempermudah pemakainya dalam mendata dan menyetok setiap persediaan obat yang telah dipesan. Saat ini sistem yang berjalan masih memiliki banyak kekurangan dan kelemahan seperti memerlukan waktu yang cukup lama dalam pemesanan obat-obatan melalui supplier sehingga menyebabkan kinerja usaha menjadi terhambat dan belum mampu menunjang segala kebutuhan yang diinginkan. Persediaan merupakan suatu aktiva yang meliputi barang milik perusahaan dengan maksut untuk dijual dalam suatu periode usaha tertentu atau persediaan barang-barang yang masih dalam pengerjaan atau proses produksi bahan baku yang menunggu penggunanya dalan suatu proses.

Dengan ini jenis obat yang mengalami kekosongan sangat memperburuk kondisi penjualan di toko Sehat Makmur sehingga mengharuskan pembeli untuk membeli obat di luar toko Sehat makmur, padahal tingkat permintaan obat oleh pembeli di toko Sehat Makmur sangat banyak. Oleh karena itu dengan "Perancangan Aplikasi Persediaan Obat pada Toko Sehat Makmur di Jakarta Timur Berbasis Java Netbeans" dapat memberikan kemudahan bagi karyawan untuk memperoleh informasi yang diinginkan. Aplikasi adalah adalah software yang dibuat oleh suatu perusahaan komputer untuk mengerjakan tugas-tugas tertentu, misalnya Microsoft Word, Microsoft Excel (Dhanta, 2015). Sistem adalah kumpulan atau himpunan dari unsur, kompenen, atau variabel yang terorganisasi, saling berinteraksi, saling tergantung satu sama lain dan terpadu (Sutabri, 2012). Informasi adalah data yang diolah menjadi bentuk yang lebih berguna dan lebih berarti bagi yang 
menerimanya, sedangkan data merupakan sumber informasi yang menggambarkan suatu kejadian yang nyata (Mulyanto, 2009). Informasi merupakan data yang telah diorganisasi dan telah memiliki kegunaan dan manfaat (Krismaji, 2016).

\section{PENELITIAN RELEVAN}

Pendekatan penelitian berkaitan dengan tujuan utama penelitian, maka peneliti menggunakan bahan refrensi berbagai sumber, antara lain dari jurnal yang relavan dalam penelitian yang peneliti lakukan, berikut adalah penelitian yang peneliti jadikan sebagai penelitian relevan:

Penelitian oleh (Sari, 2017) dengan judul Rancang Bangun Aplikasi Penjualan dan Persediaan Obat pada Apotek Merben. Hasil penelitiannya adalah dengan adanya aplikasi persediaan obat yang diusulkan pada Apotek Merben mampu menghasilkan informasi yang cepat, dan tepat waktu sehingga memudahkan dalam pengolahan data penjualan obat dan data stok obatnya. Dengan adanya aplikasi ini diharapkan dapat membantu pengguna ataupun user dalam pengolahan data penjualan, laporan obat keluar, laporan obat masuk, dan laporan cek stok obat.

Penelitian relevan selanjutnya oleh (Indarti et al., 2019) dengan judul Pengendalian Persediaan Obat Dengan Minimum-Maximum Stock. Hasil penelitiannya adalah dengan adanya aplikasi ini memiliki tujuan untuk mengetahui pengaruh metode minimum-maximum stock level (MSL) pada definisi efektivitas without control group design diterapkan dan pengendalian persediaan obat yang tidak tepat dapat menyebabkan kekurangan atau kelebihan stock persediaan obat hal ini menjadi perhatian penting untuk RSUP Dr. Sardjito Yogyakarta.

\section{METODE PENELITIAN}

Metode penelitian ini digunakan oleh peneliti pada penelitian ini adalah metode grounded (Research and Development) yang termasuk dalam metode kualitatif yaitu suatu metode penelitian yang berdasarkan fakta dan menggunakan analisis perbandingan bertujuan untuk mengadakan generalisasi empiris, menetap konsep-konsep, membuktikan teori, dan mengembangkan teori dimana pengumpulan data dan analisis data berjalan pada waktu yang bersamaan. Metode pengumpulan data yang dilakukan oleh peneliti untuk mendapatkan data-data serta informasi untuk mendukung penyempurnaan hasil dari penelitian ini antara lain Studi Pustaka, Pengamatan Langsung, Wawancara, dan Dokumentasi.

\section{HASIL DAN PEMBAHASAN}

\section{Diagram Alur Data (DAD) Yang Diusulkan}

Pada sistem perancangan persediaan obat ini, akan dibuatkan diagram Konteks, diagram Nol sebagai berikut:

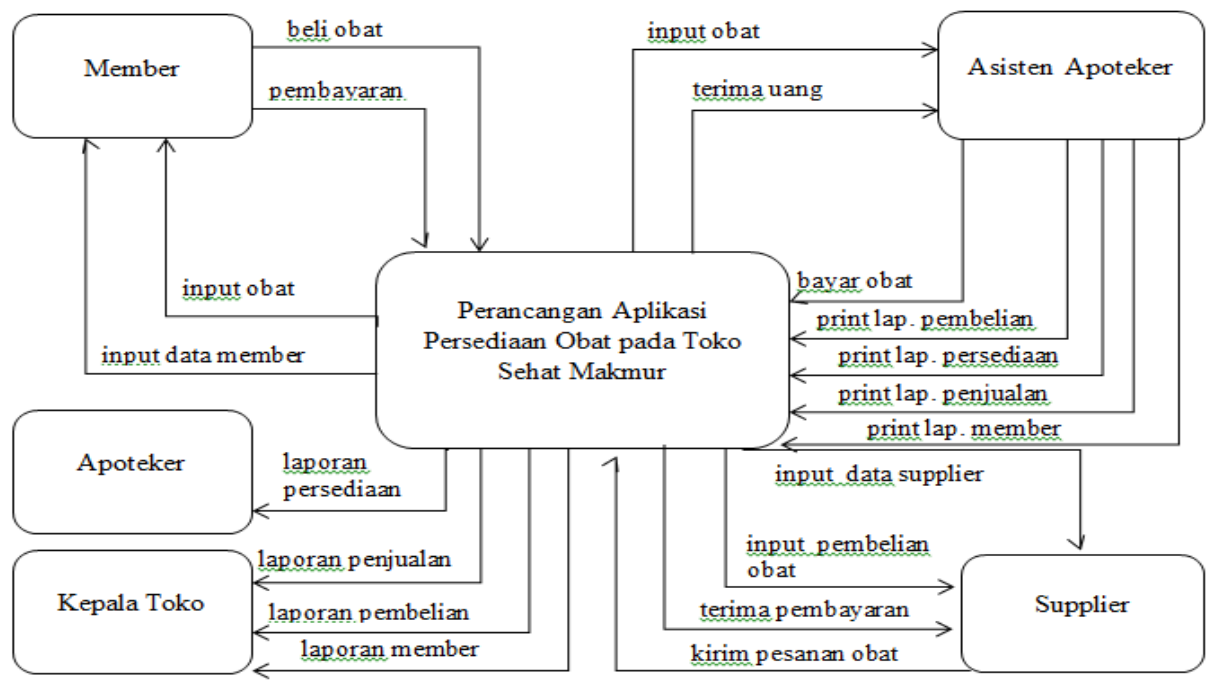

Gambar 1. Diagram Konteks 


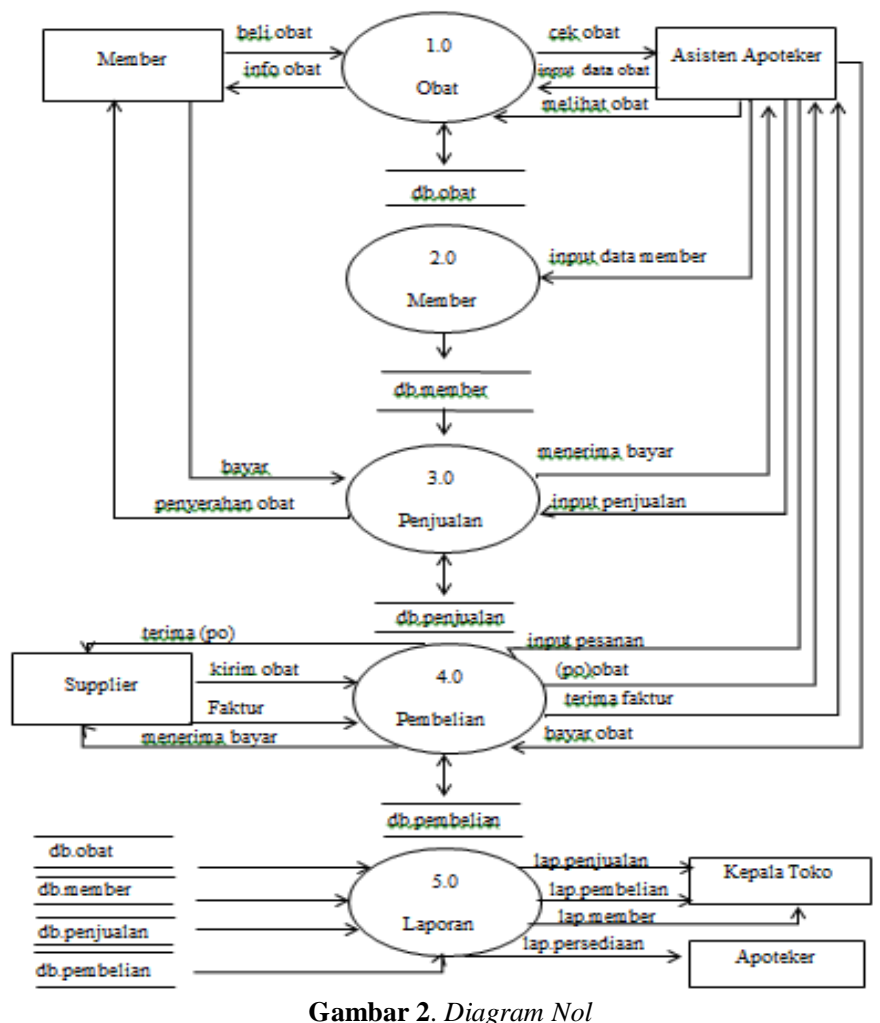

\section{Entity Relationship Diagram (ERD)}

Berikut gambar diagram Entity Relationship Diagram (ERD) yang akan diusulkan pada Toko Sehat Makmur, sebagai berikut:

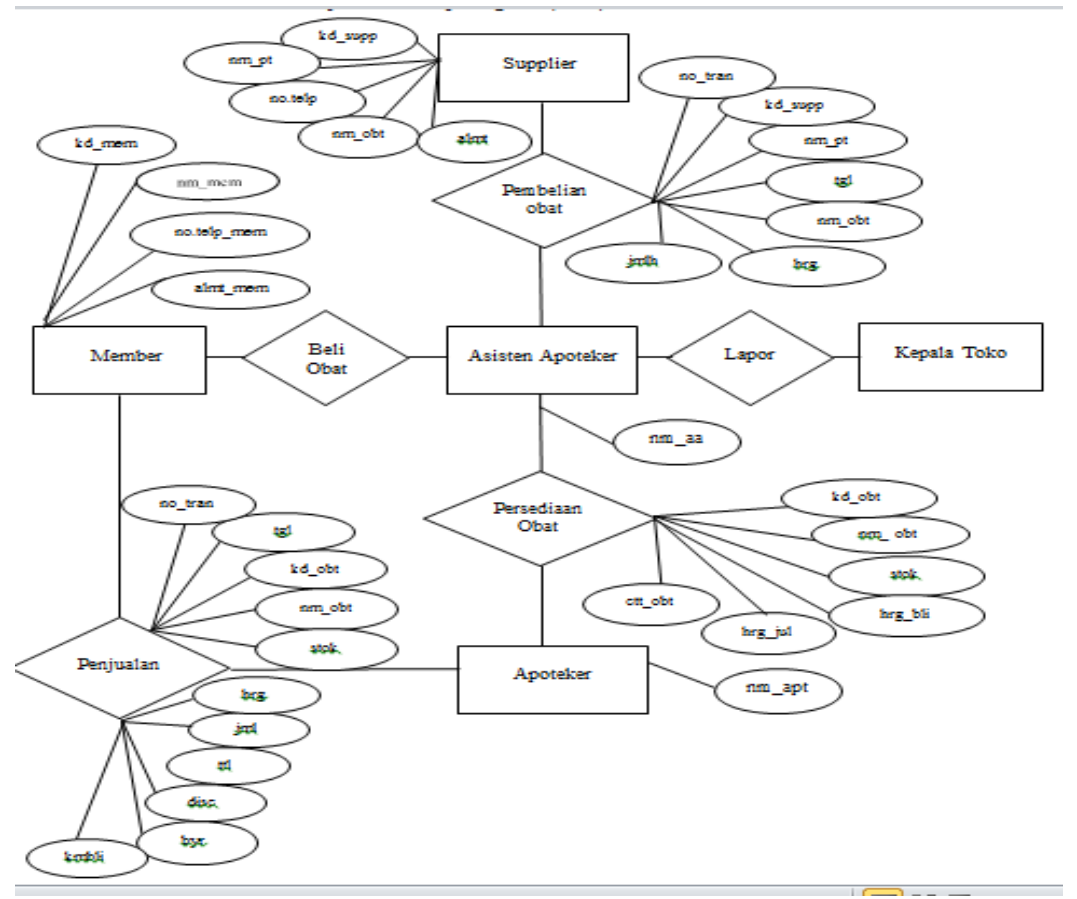

Gambar 3. Entity Relationship Diagram (ERD) 


\section{Tampilan Aplikasi}

Tampilan Login

\section{LOGIN HERE}

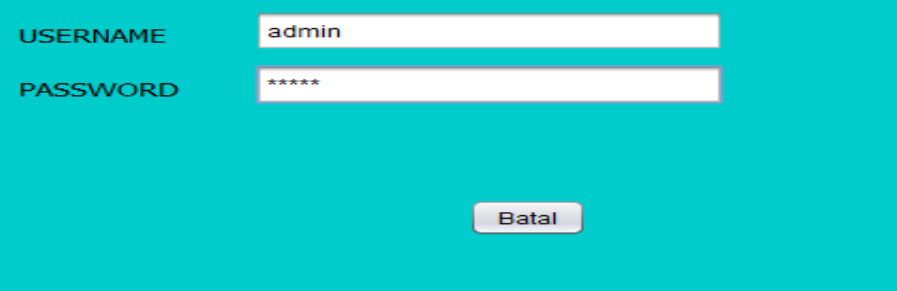

Gambar 4. Tampilan Login

Menampilkan user dan password untuk masuk kedalam aplikasi.

\section{Tampilan Menu Utama}

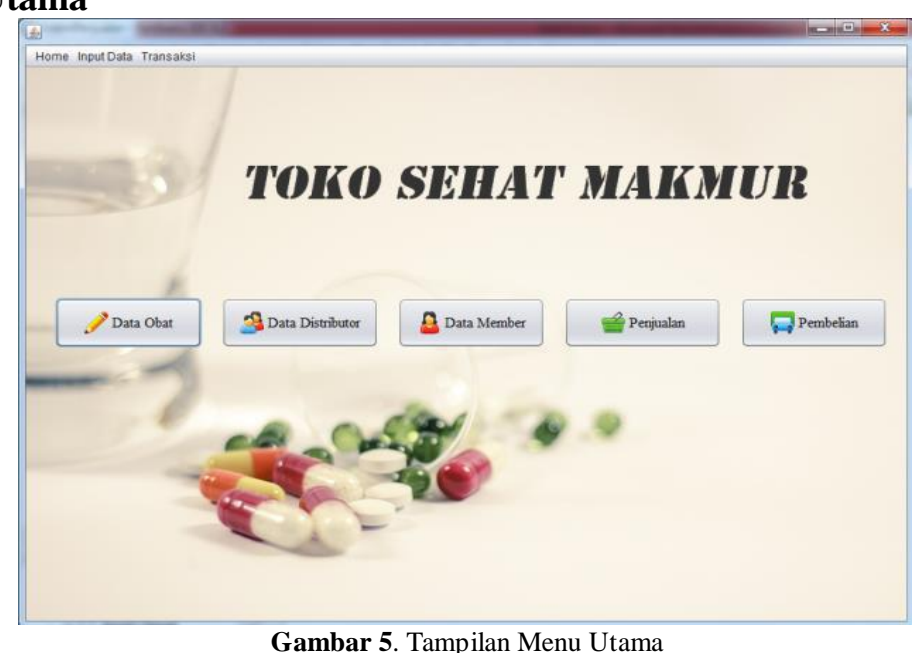

Menampilkan menu kategori aplikasi yang akan dipilih/digunakan.

\section{Tampilan Data Persediaan Obat}

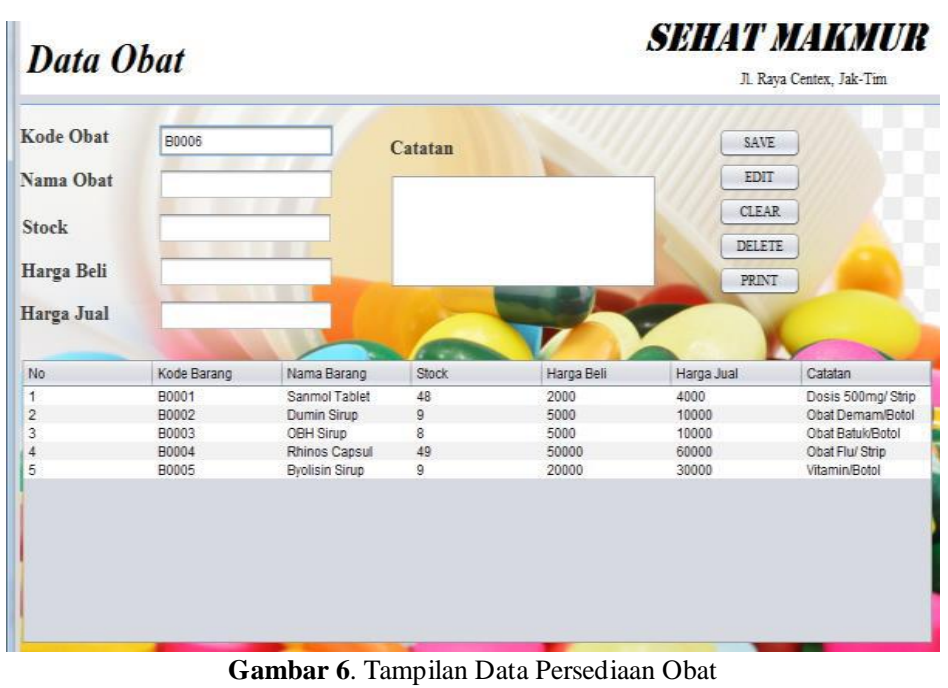

Menampilkan menu persediaan obat untuk menghitung data obat masuk dan obat keluar. 


\section{Tampilan Data Pembelian Obat}

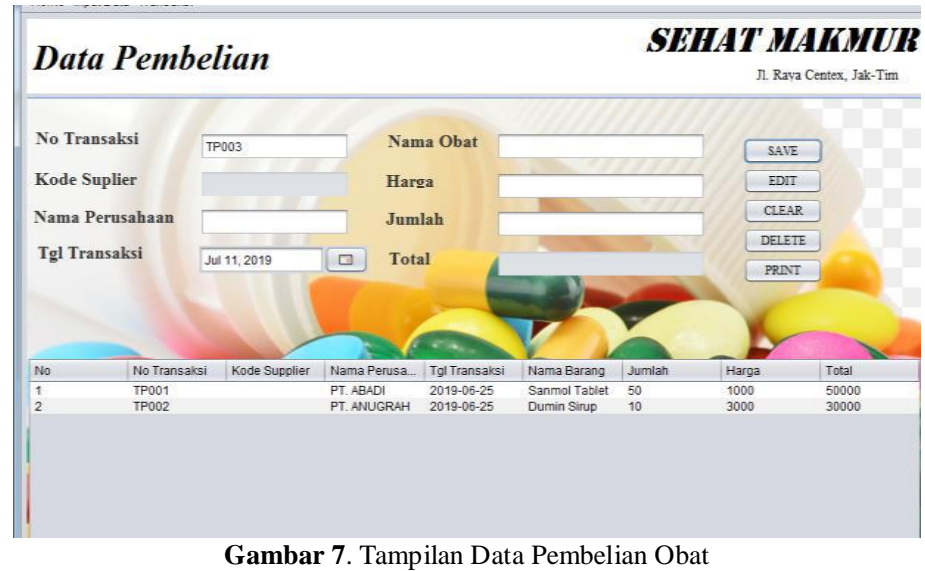

Menampilkan catatan data pembelian/ pemesanan obat kepada distributor yang akan dipesan.

\section{Tampilan Data Penjualan Obat}

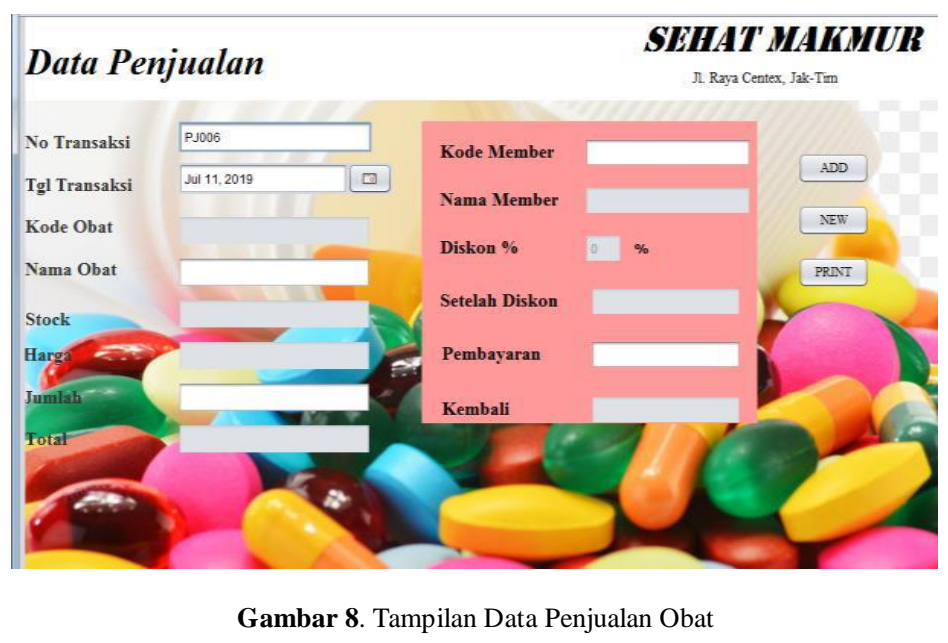

Menampilkan laporan penjualan harian yang akan direkap secara baik.

\section{Rancangan Data Supplier}

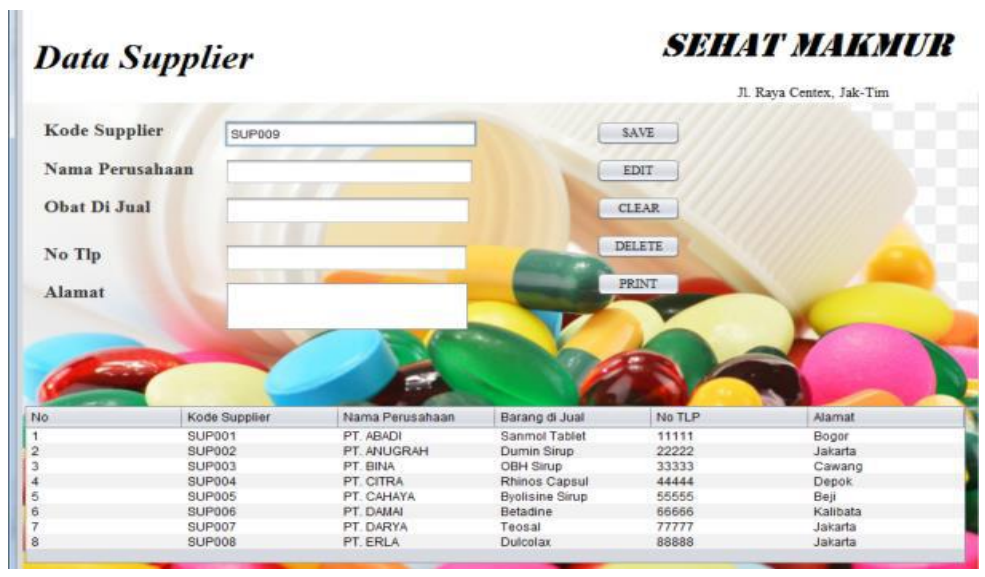

Gambar 9. Tampilan Data Supplier

Menampilkan data distributor untuk pemesanan data obat. 


\section{SIMPULAN}

Dengan adanya sistem aplikasi ini akan membawa keuntungan bagi Toko Sehat Makmur, diharapkan dapat mempercepat proses kerja karyawan dan memudahkan pelanggan dalm membeli obat, karena sistem ini telah dilengkapi dengan sistem database sehingga mempercepat proses persediaan obat dan penjualan obat. Dengan program sistem aplikasi persediaan obat, akan lebih mudah dan memberikan informasi kepada pelanggan akan lebih cepat dibandingkan dengan pencarian obat dengan cara manual yaitu dengan melihat obat secara fisik yang menghambat proses waktu penjualan.

\section{DAFTAR PUSTAKA}

Dhanta. (2015). Aplikasi Berbasis Web, ” Apl. Berbas. Web.

Indarti, T. R., Satibi, S., \& Yuniarti, E. (2019). Pengendalian Persediaan Obat dengan Minimum-Maximum Stock Level di Instalasi Farmasi RSUP Dr. Sardjito Yogyakarta. JURNAL MANAJEMEN DAN PELAYANAN FARMASI (Journal of Management and Pharmacy Practice), 9(3), 192. https://doi.org/10.22146/jmpf.45295.

Krismaji. (2015). Sistem Informasi Akuntansi. Yogyakarta: UPP AMP YKPN

Mulyanto, Agus. (2009). Sistem Informasi Konsep dan Aplikasi. Yogyakarta: Pustaka Pelajar.

Sari, Y. P. (2017). Rancang Bangun Aplikasi Penjualan Dan Persediaan Di Kota Prabumulih. Jurnal Sistem Informasi Dan Komputerisasi Akuntansi (JSK), 1(1), 81-88. http://jsk.ac.id/index.php/JSK/article/view/11.

Sutabri, Tata. (2012). Analisis Sistem Informasi. 2012. Yogyakarta: Andi 